\title{
EVALUASI PROGRAM IbM PENDAMPINGAN PENYUSUNAN BORANG AKREDITASI BAGI SEKOLAH DASAR DI KOTA TERNATE
}

\author{
Mardia Hi Rahman ${ }^{1}$, Saprudin $^{2}$, Husnin Mubarak ${ }^{3}$, dan Fatma Hamid ${ }^{4}$ \\ 1,2,3,4 Program Studi Pendidikan Fisika, Universitas Khairun \\ *Saprudin_unkhair@yahoo.com
}

\begin{abstract}
Abstrak
Akreditasi sekolah/ madrasah merupakan proses penilaian secara komprehensif terhadap kelayakan dan kinerja satuan dan/ atau program, yang dilakukan sebagai bentuk akuntabilitas publik. Kenyataan menunjukkan bahwa masih terdapat banyak sekolah/ madrasah yang ada di Kota Ternate yang harus di re-akreditasi tahun 2017. SDA merupakan sekolah mitra lbM yang sudah dua kali diakreditasi yaitu pada tahun 2007 dengan peringkat akreditasi A, sementara tahun 2012 re-akreditasi dan terakreditasi dengan peringkat C. SD-B merupakan sekolah mitra IbM yang telah diakreditasi tahun 2012 dengan peringkat akreditasi C. Program pendampingan penyusunan borang akreditasi bagi Sekolah Dasar di kota Ternate merupakan salah satu program pengabdian yang dilakukan berupa; 1) transfer pengetahuan terkait pentingnya akreditasi sekolah, 2) pelatihan intensif terkait penyusunan borang akreditasi sekolah, 3) pendampingan penyusunan borang akreditasi bagi sekolah mitra. Adanya program pengabdian masyarakat ini berdampak terhadap peningkatan pemahaman sekolah mitra terkait akreditasi sehingga dapat menumbuhkan kesadaran serta meningkatkan tanggung jawab sekolah mitra untuk meningkatkan status akreditasi sekolah.
\end{abstract}

Kata kunci: IbM, Pendampingan, Borang Akreditasi

\section{PENDAHULUAN}

Akreditasi sekolah/ madrasah merupakan proses penilaian secara komprehensif terhadap kelayakan dan kinerja satuan dan/ atau program, yang dilakukan sebagai bentuk akuntabilitas publik (Antonius, 2014). Proses pelaksanaan akreditasi pada suatu sekolah/ madrasah merupakan evaluasi yang berkaitan dengan arah dan tujuan sekolah/madrasah serta seluruh kondisi sekolah/ madrasah. Proses pelaksanaan akreditasi sekolah/madrasah mengacu pada standar nasional pendidikan. Salah satu tujuan penting dari kebijakan akreditasi adalah untuk menentukan kelayakan satuan pendidikan pada jalur formal maupun non formal pada setiap jenjang dan jenis pendidikan dalam rangka memenuhi delapan standar nasional pendidikan (UU No. 20 tahun 2003).

Sekolah/madrasah yang telah diakreditasi di provinsi Maluku Utara dari tahun 2007 hingga 2015 sebanyak $2758 \mathrm{~S} / \mathrm{M}$ dengan peringkat akreditasi yang bervariasi yaitu A, B, dan C. Masih banyak sekolah/ madrasah yang ada di Kota Ternate yang harus di re-akreditasi terutama untuk tahun 2017 dan 2018, namun tidak semua akan dapat diakreditasi karena keterbasan kuota, sehingga sekolah/ madrasah yang terakreditasi dengan peringkat $C$ akan diprioritaskan. Hal ini dimaksudkan untuk meningkatkan peringkat akreditasinya, tetapi sekolah/ madrasah harus dapat mempersiapkan diri untuk di akreditasi ulang (BAP-S/M Prov. Maluku Utara, 2012 - 2015).

Sekolah/ madrasah yang harus diusulkan untuk diakreditasi ulang pada tahun 2017 dan 2018 di Kota Ternate terutama yang memperoleh peringkat $C$ pada jenjang SD/ MI sebanyak 20, SMP/ MTs sebanyak 3, dan SMA/ MA sebanyak 3 (BAP-S/M Prov. Maluku Utara, 2012 - 2015). Dari 20 SD/ MI yang akan diakreditasi ulang tahun 2017 dan 2018 tersebut maka sekolah/ madrasah yang diperioritaskan adalah SD-A dan SD-B yang merupakan sekolah mitra program IbM ini.

SD-A merupakan salah satu sekolah yang berada dipusat keramaian dan memiliki siswa terbanyak dari 3 sekolah lain di kelurahan Bastiong Karance. Sekolah ini memiliki 387 siswa dengan 12 rombongan belajar. Sekolah ini sudah dua kali diakreditasi yaitu pada tahun 2007 dengan peringkat akreditasi A dengan nilai 86 namun pada tahun 2012 diakreditasi ulang dan terakreditasi dengan peringkat $C$ yakni dengan nilai 60 . Dari hasil tersebut terlihat bahwa sekolah ini mengalami penurunan 
yang drastis. Salah satu faktor yang menyebabkan sekolah ini menurun peringkat akreditasinya adalah ketidakpedulian pihak sekolah untuk memacu dan meningkatkan mutu sekolah.

Walaupun pada pelaksanaan akreditasi pertama tahun 2007 menggunakan perangkat instrumen lama dan pada saat reakreditasi menggunakan instrumen baru. Instrumen akreditasi 2007 menggunakan instrumen dengan sembilan komponen yaitu (a) kurikulum dan proses belajar mengajar; (b) administrasi dan manajemen sekolah; (c) organisasi dan kelembagaan sekolah; (d) sarana prasarana (e) ketenagaan; (f) pembiayaan; (g) peserta didik; (h) peran serta masyarakat; dan (i) lingkungan dan kultur sekolah sedangkan sejak tahun 2008 menggunakan instrumen yang mengacu pada delapan standar nasional pendidikan yakni (a) standar isi; (b) standar proses; (c) standar kompetensi lulusan; (d) standar pendidik dan tenaga kependidikan (tendik); (e) standar sarana dan prasarana; (f) standar pengelolaan; (g) standar pembiayaan; dan (h) standar penilaian. Namun seharusnya bukan masalah instrumen yang berbeda tetapi yang harus dilakukan pihak sekolah adalah melaksanakan evaluasi kinerjanya setiap saat.

Berdasarkan hasil studi dokumentasi nilai setiap komponen yang diperoleh SD-A, teridentifikasi sejumlah kekurangan seperti ditunjukkan pada Tabel 1.

Tabel 1. Nilai komponen akreditasi setiap standar SD-A

\begin{tabular}{clc}
\hline No & \multicolumn{1}{c}{ Komponen Akreditasi } & Nilai Komponen Akreditasi \\
\hline 1 & Standar Isi & 56 \\
2 & Standar Proses & 62 \\
3 & Standar Kompetensi Lulusan & 55 \\
4 & Standar pendidik dan tenaga kependidikan & 65 \\
5 & Standar Sarana dan Prasarana & 59 \\
6 & Standar Pengelolaan & 58 \\
7 & Standar Pembiayaan & 56 \\
8 & Standar Penilaian & 61 \\
\hline & Peringkat Akreditasi & $60(\mathrm{C})$ \\
\hline
\end{tabular}

Sumber Data : BAP-S/M Prov. Maluku Utara (2012)

SD-B merupakan sekolah yang berada di selatan Kota Ternate yang diharapkan dapat mengembangkan sekolahnya karena berada disekitar kampus-kampus di Kota Ternate baik negeri maupun swasta. Sekolah ini memiliki siswa sebanyak 163 siswa dengan luas lahan $1.596 \mathrm{~m}^{2}, 6$ rombongan belajar, 6 ruang belajar serta memiliki perpustakaan yang cukup memadai. Namun dalam hal pelaksanaan evaluasi diri sekolah untuk memperbaiki kinerja sekolah kurang maksimal sehingga berakibat pada hasil akreditasi yang berada pada kategori cukup. Sekolah ini diakreditasi pada tahun 2012. Sekolah ini memiliki beberapa guru yang dapat dikategorikan kreatif dalam proses pembelajaran, dan apabila guru-guru tersebut dilibatkan dalam tim pengembang sekolah maka sekolah ini kemungkinan besar akan meningkat mutunya. Dari hasil akreditasi yang diperoleh yang menjadi kelemahan adalah sekolah tidak dapat mendokumenkan dan menata segala bentuk kegiatan secara baik. Atau bahkan kepala sekolah tidak dapat menerapkan manajemen kepemimpinan yang baik, yang dapat dicontoh atau dapat memotivasi guru untuk meningkatkan kinerjanya.

Berdasarkan hasil studi dokumentasi nilai setiap komponen yang diperoleh SD-B, teridentifikasi sejumlah kekurangan seperti ditunjukkan pada Tabel 2.

Tabel 2. Nilai komponen akreditasi setiap standar SD-B

\begin{tabular}{clc}
\hline No & \multicolumn{1}{c}{ Komponen Akreditasi } & Nilai Komponen Akreditasi \\
\hline 1 & Standar Isi & 59 \\
2 & Standar Proses & 64 \\
3 & Standar Kompetensi Lulusan & 58 \\
4 & Standar pendidik dan tenaga kependidikan & 62 \\
5 & Standar Sarana dan Prasarana & 66 \\
6 & Standar Pengelolaan & 53 \\
7 & Standar Pembiayaan & 70 \\
8 & Standar Penilaian & 78 \\
\hline & Peringkat Akreditasi & 63 (C) \\
\hline
\end{tabular}


Mardia Hi Rahman, Saprudin, Husnin Mubarak, dan Fatma Hamid

Dari data hasil akreditasi kedua sekolah terlihat bahwa sekolah memiliki kelemahan pada setiap standar, sehingga tidak memenuhi kriteria untuk terakreditasi dengan peringkat B apalagi A. Padahal instrumen akreditasi berdasarkan pada SNP dan sudah dilakukan oleh baik kepala sekolah, guru, maupun warga sekolah yang lain bahkan oleh pemerintah. Dengan kata lain bahwa jika akreditasi oleh sekolah dipandang sebagai kebutuhan bagi sekolah, maka pihak sekolah akan serius melaksanakan. Persiapan akreditasi yang dilakukan oleh sekolah seharusnya tidak sampai menunggu sekolahnya akan diakreditasi lantas dengan sibuk pihak sekolah mempersiapkan semua administrasi yang terkait dengan akreditasi, akan tetapi pihak sekolah harus menyadari bahwa dalam menjalankan roda kehidupan sekolah, pihak sekolah telah menerapkan delapan standar nasional pendidikan yang semuanya sudah dibagi kewenangannya sendiri-sendiri.

Program pendampingan penyusunan borang akreditasi bagi Sekolah Dasar di kota Ternate merupakan salah satu program pengabdian kepada masyarakat yang dilakukan berupa; 1) transfer pengetahuan terkait pentingnya akreditasi sekolah, 2) pelatihan intensif terkait penyusunan borang akreditasi sekolah, 3) pendampingan penyusunan borang akreditasi bagi sekolah mitra.

Untuk menelusuri efektivitas dan efisiensi pelaksanaan suatu program, maka perlu dilaksanakan evaluasi program. Fitzpatrick et. al. (2012) mengungkapkan bahwa evaluasi adalah mengidentifikasi, mengklarifikasi dan menerapkan sejumlah kriteria untuk mendeterminasi manfaat atau nilai dari suatu objek evaluasi. Posavac and Carey (Firman, 2017) mengemukakan bahwa evaluasi program merupakan pengumpulan informasi yang sistematis tentang kegiatan, karakteristik dan hasil program untuk membuat penilaian tentang program, meningkatkan keefektifan program, dan atau menginformasikan keputusan tentang program pada masa yang akan datang.

Adanya program $\mathrm{IbM}$ ini diharapkan dapat meningkatkan pemahaman sekolah mitra terkait penilaian akreditasi sekolah, peningkatan keterampilan sekolah mitra dalam menyusun borang akreditasi sekolah sehingga dengan bekal pemahaman yang baik dan pendampingan yang dilakukan maka diharapkan sekolah mitra dapat lebih siap dalam menghadapi re-akreditasi yang ditunjukkan dengan tersedianya borang akreditasi sekolah yang didukung dengan kelengkapan dokumen penunjang, sehingga pada akhirnya diharapkan dapat meningkatkan peringkat akreditasi sekolah.

\section{METODE}

Program pendampingan penyusunan borang akreditasi bagi Sekolah Dasar di kota Ternate dilaksanakan dalam bentuk pengabdian kepada masyarakat skema Ipteks Bagi Masyarakat (IbM) yang secara umum terdiri dari 5 tahap; a) survey pendahuluan, b) pelatihan, c) pendampingan (implementasi pelatihan), d) evaluasi dan e) refleksi. Data dikumpulkan melalui tes, wawancara, observasi dan studi dokumentasi.

\section{HASIL DAN PEMBAHASAN}

\section{Gambaran Umum Program Pendampingan Penyusunan Borang Akreditasi Bagi Sekolah Dasar di Kota Ternate}

Program pengabdian kepada masyarakat ini terdiri dari 5 tahap yakni; survey pendahuluan, pelatihan, pendampingan (implementasi pelatihan), evaluasi dan refleksi. Paparan masing- masing pelaksanaan kegiatan akan diuraikan sebagai berikut.

a. Survey Pendahuluan

Survey pendahuluan dilakukan melalui FGD (Focus Group Discussion) dan studi dokumentasi hasil penilaian akreditasi pada sekolah mitra yang menghasilkan temuan permasalahanpermasalahan yang dihadapi ke 2 sekolah mitra. Selanjutnya dilakukan wawancara mendalam (indept interview) dengan ke 2 sekolah mitra sehingga dapat disepakati permasalahan prioritas yang diselesaikan dengan program IbM ini.

b. Pelatihan 
Pelatihan diberikan sekolah mitra yakni SD-A dan SD-B. Adapun lingkup materi pelatihan meliputi; 1) Peran akreditasi dalam penjaminan mutu pendidikan, 2) Mekanisme akreditasi sekolah/ Menengah, 3) Perangkat akreditasi SD/ MI, 4) Penjelasan pengisian borang akreditasi $\mathrm{SD} / \mathrm{MI}$, 5) Pedoman penilaian instrumen akreditasi SD/ MI, 6) Pedoman dan fokus kajian asesmen lapangan, 7) Praktik penyusunan Borang akreditasi SD/ MI.

c. Pendampingan

Setelah pelatihan dilaksanakan, masing-masing sekolah mitra akan mendapatkan pendampingan dalam penyusunan borang akreditasi sekolah. Tujuan dari pendampingan ini adalah untuk mendampingi sekolah mitra dalam penyusunan borang akreditasi dan juga menjadi fasilitator dalam menyiapkan bukti fisik borang akreditasi yang mengacu pada instrumen akreditasi SD/ MI sehingga sekolah mitra dapat menyiapkan segala bentuk dokumen sesuai instrumen penilaian akreditasi. Pendampingan dilaksanakan lebih difokuskan pada diskusi dan sharing informasi terkait penyiapan bukti fisik yang biasanya menjadi bahan penilaian akreditasi SD/ MI yang terdiri dari 119 butir instrumen yakni; standar isi (instrumen $1-10$ ), standar proses (instrumen $11-31$ ), standar kompetensi lulusan (instrumen 32 - 38), standar pendidik dan tenaga kependidikan (instrumen 39 - 54), standar sarana dan prasarana (instrumen 55 - 75), standar pengelolaan (instrumen 76 - 90), standar pembiayaan (instrumen 91 - 106) dan standar penilaian (instrumen $107-119)$.

d. Evaluasi

Setelah proses pendampingan selesai, maka dilakukan evaluasi untuk melihat dampaknya terhadap kualitas borang akreditasi yang dihasilkan. Evaluasi ini dilakukan dengan melakukan penilaian akreditasi yang serupa dengan penilaian akreditasi sekolah yang dilaksanakan oleh Badan Akreditasi Sekolah/ madrasah.

e. Refleksi

Pada tahap ini, dilaksanakan refleksi terkait pelaksanaan program pengabdian kepada masyarakat yang telah dilaksanakan melalui forum diskusi. Adanya forum ini diharapkan dapat terjadi saling tukar pengalaman antar sekolah mitra dengan tim pelaksana program pengabdian berperan sebagai fasilitator maupun supervisor. Hasil kegiatan refleksi ini diharapkan berupa pengalaman bagi sekolah mitra dalam mempersiapkan segala bentuk dokumen akreditasi sekolah.

\section{Dampak Program Pendampingan Penyusunan Borang Akreditasi bagi Sekolah Mitra}

a. Peningkatan Pemahaman Sekolah Mitra terkait Akreditasi Sekolah

Transfer pengetahuan terkait pentingnya akreditasi dapat dilakukan melalui pelatihan penyusunan borang akreditasi bagi sekolah/madrasah.

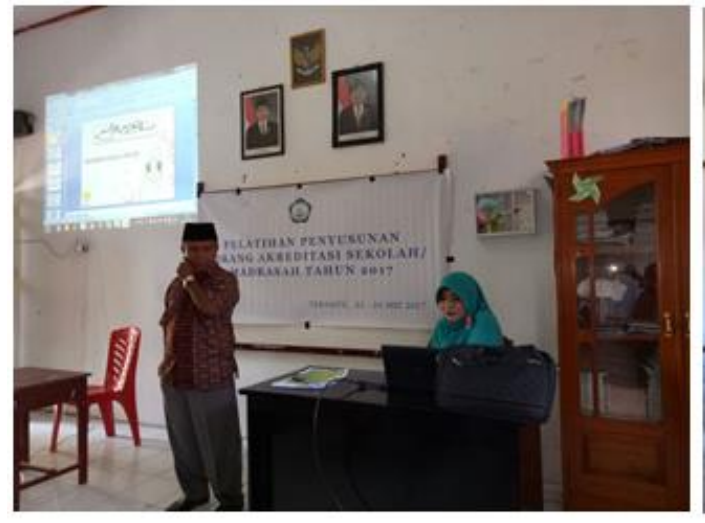

(1.a)

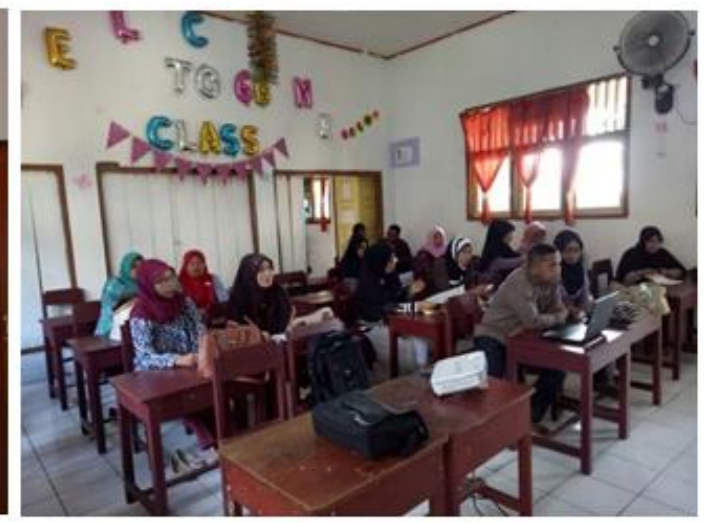

(1.b)

Gambar 1. Penyampaian Materi Pada Pelatihan Penyusunan Borang Akreditasi Sekolah/ Madrasah 
Materi peran akreditasi dalam penjaminan mutu pendidikan; pemaparan materi ini dapat memberi pemahaman guru-guru dan kepala sekolah pada ke dua Sekolah mitra terkait dasar hukum, tujuan, fungsi, dan manfaat akreditasi sekolah/ madrasah khususnya akreditasi Sekolah Dasar. Adanya pemahaman yang baik dapat menumbuhkan kesadaran akan pentingnya akreditasi sekolah.

Materi mekanisme akreditasi Sekolah/ Menengah; pemaparan materi ini dapat memberi pemahaman guru-guru dan kepala sekolah pada ke dua Sekolah mitra terkait tingkat dan kewenangan badan akreditasi sekolah/ madrasah, unsur-unsur dalam pelaksanaan akreditasi sekolah/ madrasah, mekanisme akreditasi sekolah/ madrasah khususnya Sekolah Dasar baik secara manual (offline) maupun online.

Materi perangkat akreditasi SD/Ml; pemaparan materi ini dapat memberi pemahaman guru-guru dan kepala sekolah pada ke dua Sekolah mitra terkait perangkat akreditasi akreditasi SD/ MI yang digunakan dalam proses akreditasi SD/ MI berdasarkan pada peraturan menteri pendidikan dan kebudayaan nomor 002/H/AK/2017 tentang kriteria dan perangkat akreditasi SD/ MI.

Materi terkait penjelasan pengisian borang akreditasi SD/ MI; pemaparan materi ini dapat memberi pemahaman guru-guru dan kepala sekolah pada ke dua Sekolah mitra terkait pengisian borang akreditasi yang difokuskan pada pengisian instrumen beserta penjelasan tentang bukti fisik yang biasanya menjadi bahan penilaian yakni; standar isi yakni butir instrumen $1-10$, standar proses yakni butir instrumen $11-31$, standar kompetensi lulusan yakni butir instrumen $32-38$, standar pendidik dan tenaga kependidikan yakni butir instrumen $39-54$, standar sarana dan prasarana yakni butir instrumen $55-75$, standar pengelolaan yakni butir instrumen $76-90$, standar pembiayaan yakni butir instrumen 91 - 106 dan standar penilaian yakni butir instrumen $107-119$ (BAN SM, 2017).

Materi pedoman penilaian instrumen akreditasi SD/ Ml; pemaparan dan diskusi materi ini memberikan pemahaman guru-guru dan kepala sekolah pada kedua mitra terkait penskoran instrumen akreditasi (bobot komponen instrumen akreditasi, bobot butir instrumen akreditasi, skor butir instrumen akreditasi, perhitungan jumlah skor tertimbang maksimum, perhitungan nilai akhir akreditasi, penentuan nilai komponen akreditasi skala ratusan), kriteria status akreditasi dan pemeringkatan hasil akreditasi (kriteria status akreditasi, pemeringkatan hasil akreditasi). Adanya pemaparan materi ini dapat memberi pemahaman sekaligus bahan evaluasi diri akan kekuatan dan kelemahan sekolah mitra sehingga sekolah mitra dapat lebih siap dalam menghadapai akreditasi sekolah.

Materi pedoman dan fokus kajian asesmen lapangan; pemaparan materi ini memberikan gambaran tentang asesmen lapangan yang dilakukan oleh asesor sehingga sekolah mitra dapat lebih jelas dalam memberikan informasi data sekolah sesuai dengan keadaan yang sebenarnya.

Praktik penyusunan Borang akreditasi SD/ Ml; untuk praktek materi ini dilakukan di sekolah masing-masing dikarenakan data-data yang diperlukan masih terdapat di sekolah. Guru-guru dan kepala sekolah pada kedua Sekolah mitra didampingi oleh fasilitator dari tim pengabdian kepada masyarakat.

\section{b. Peningkatan Kesiapan Dokumen Fisik Penunjang Borang Akreditasi di Sekolah Mitra}

Hasil analisis dokumen penunjang borang akreditasi selama proses pendampingan pada kedua sekolah mitra dapat ditunjukkan pada Tabel 3. 
Tabel 3. Analisis Kesiapan Dokumen Penunjang Borang Akreditasi

\begin{tabular}{|c|c|c|c|}
\hline \multirow[t]{2}{*}{ No } & \multirow[t]{2}{*}{ Komponen Akreditasi } & \multicolumn{2}{|c|}{$\begin{array}{l}\text { Persentase kesiapan dokumen } \\
\text { penunjang borang akreditasi (\%) }\end{array}$} \\
\hline & & SD-A & SD-B \\
\hline 1 & Standar Isi & 90 & 80 \\
\hline 2 & Standar Proses & 90 & 75 \\
\hline 3 & $\begin{array}{l}\text { Standar Kompetensi Lulusan } \\
\text { Standar Pendidik dan Tenaga }\end{array}$ & 80 & 80 \\
\hline 4 & Kependidikan & 90 & 80 \\
\hline 5 & Standar Sarana dan Prasarana & 90 & 75 \\
\hline 6 & Standar Pengelolaan & 85 & 70 \\
\hline 7 & Standar Pembiayaan & 80 & 70 \\
\hline 8 & Standar Penilaian & 80 & 70 \\
\hline \multicolumn{2}{|r|}{$\begin{array}{l}\text { Rerata tingkat kesiapan dokumen pendukung } \\
\text { borang akreditasi }\end{array}$} & 86 & 75 \\
\hline
\end{tabular}

Hasil analisis menunjukkan bahwa, tingkat kesiapan dokumen pendukung borang akreditasi sekolah pada sekolah mitra SD-A dapat dikategorikan sangat baik (86\%), sedangkan sekolah mitra SD-B dikategorikan baik (75\%). Adanya kelengkapan dokumen pendukung borang akreditasi menunjukkan adanya tanggung jawab dan kesiapan sekolah mitra dalam menghadapi reakreditasi sekolah yang pada akhirnya diharapkan dapat meningkatkan peringkat akreditasi.

\section{PENUTUP}

\section{Kesimpulan}

Berdasarkan hasil analisis evaluasi pelaksanaan program pendampingan penyusunan borang akreditasi bagi Sekolah Dasar di kota Ternate disimpulkan bahwa;

1. Transfer pengetahuan terkait pentingnya akreditasi di sekolah mitra dapat dilakukan melalui pelatihan penyusunan borang akreditasi. Adanya peningkatan pemahaman sekolah mitra terkait akreditasi dapat menumbuhkan kesadaran serta meningkatkan tanggung jawab sekolah mitra untuk meningkatkan status akreditasi sekolah.

2. Pendampingan yang dilakukan dapat memfasilitasi sekolah mitra dalam menyiapkan dokumen pendukung borang akreditasi. Adanya kelengkapan dokumen pendukung borang akreditasi menunjukkan kesiapan sekolah mitra dalam menghadapi proses re-akreditasi.

\section{DAFTAR PUSTAKA}

Antonius, 2014 Pelaksanaan Akreditasi Sekolah Dasar Negeri, Fokus, Jilid 12, Nomor 2, Maret 2014

BAN SM. 2017. Perangkat Akreditasi SD/ MI. Jakarta: Badan Akreditasi Nasional Sekolah/ Madrasah

BAP-S/M Prov. Maluku Utara. 2012. Laporan BAP-S/M Prov. Maluku Utara tahun 2012

BAP-S/M Prov. Maluku Utara. 2013. Laporan BAP-S/M Prov. Maluku Utara tahun 2013

BAP-S/M Prov. Maluku Utara. 2014. Laporan BAP-S/M Prov. Maluku Utara tahun 2014

BAP-S/M Prov. Maluku Utara. 2015. Laporan BAP-S/M Prov. Maluku Utara tahun 2015 
Mardia Hi Rahman, Saprudin, Husnin Mubarak, dan Fatma Hamid

Firman Harry. 2017. Evaluasi Program (Pengantar); Bahan Kuliah Evaluasi Program Pendidikan IPA. Tidak diterbitkan

Fitzpatrick, J.L., Sanders, J.R., \& Worthen, R.B. (2012) Program Evaluation: Alternative Approaches and Practical Guidelines. New Jersey: Pearson Education.

Undang-Undang Nomor 20 Tahun 2003 tentang Sistem Pendidikan Nasional. 